Artykuly / Articles

Дмитрий Афанасьев

ORCID 0000-0002-2157-0331

dmytro.afanasiev@uzhnu.edu.ua

Кристина Новосад

ORCID 0000-0003-3335-6532

novosadkristina28@gmail.com

Руслана Джуган

ORCID 0000-0002-5999-7752

ruslana.sopko@gmail.com

Ужгородский национальный университет

Факультет общественных наук

Украина

\title{
Особенности дистанционного образования ромских детей в условиях COVID-191
}

\author{
Features of distance education of Roma children \\ in the conditions of COVID-19 \\ Specyfika kształcenia na odległość dzieci romskich \\ w warunkach COVID-19 \\ DOI: $10.34739 /$ doc.2020.17.06
}

\begin{abstract}
Аннотация: В статье проанализированы результаты всеукраинского социологического исследования особенностей дистанционного образования цыганских детей в условиях пандемии. Исследование осуществлено методом опроса родителей учеников-ромов и их учителей. Актуальность исследования заключается в анализе вызовов обусловленных карантином и сопутствующих последствий в связи с распространением COVID-19. Поэтому исследования особенностей дистанционного обучения, введенного из-за карантина, показамо пробелы в системе образования и отсутствия

\footnotetext{
1 Данная статья является расширенной версией статьи, ранее опубликованной на украинском языке: Д. М. Афанасьєв, Р. І. Джуган, Надання освітніх послуг дітямромам в умовах пандемії COVID-19: результати соиіологічного дослідження, [в:] Надання соиіальних послуг в умовах деиентралізаиї: проблеми та перспективи. Матеріали доповідей та повідомлень Міжнародної науковопрактичної конферениї (м. Ужгород, 25 вересня 2020 р.), ред. О. Бартош, С. Аитвинова, В. Панок, Ф. Шандор, Ужгород 2020, с. 10-13.
} 
возможностей родителей-ромов обеспечить технические средства для доступности и приоритетности дистанционного образования дмя своих детей.

Кмючевые слова: дистанционное образование, дети-ромы, родителиромы, педагоги, условия пандемии

Abstract: The article analyzes the results of the all-Ukrainian sociological study of the features of distance education of Roma children in a pandemic. The research was conducted by interviewing the parents of Roma students and their teachers. The relevance of the study is to analyze the challenges posed by quarantine and the associated consequences of the spread of COVID-19. Therefore, the study of the features of distance learning, introduced through quarantine, showed gaps in the education system and the lack of opportunities, unwillingness of Roma parents to provide technical means for the availability and priority of distance education for their own children.

Keywords: distance education, Roma children, Roma parents, teachers, pandemic conditions

Abstrakt: W artykule przeanalizowano wyniki ogólnoukraińskiego badania socjologicznego specyfiki kształcenia na odległość dzieci romskich w warunkach pandemii. Badanie zrealizowano metoda wywiadów przeprowadzonych $z$ rodzicami uczniów romskich i ich nauczycielami. Znaczenie badania zawiera się w analizie wyzwań zwiąanych z kwarantanna i konsekwencji rozprzestrzeniania się COVID-19. Dlatego badanie cech nauczania na odległość, wprowadzonego w konsekwencji wdrożenia kwarantanny wykazało luki w systemie edukacji, brak gotowości rodziców romskich do zapewnienia środków technicznych służących dostępności i realizacji priorytetu edukacji na odległość dla własnych dzieci.

Słowa kluczowe: edukacja na odległość, dzieci romskie, rodzice romscy, nauczyciele, warunki pandemiczne

Информатизация образования в Украине - один из важнейших механизмов, затрагивающий основные направления модернизации образовательной системы. Современные информационные технологии открывают новые перспективы для повышения эффективности образовательного процесса. Меняется сама парадигма образования. Большая роль отводится методам активного познания, самообразованию, дистанционным образовательным программам. Дистанционные технологии обучения можно рассматривать как естественный этап эволюции традиционной системы образования от доски с мелом до эмектронной доски и компьютерньх обучающих систем, от 
книжной библиотеки до эмектронной, от обычной аудитории к виртуальной аудитории.

Эффективность дистанционного обучения основана на том, что обучаемые сами чувствуют необходимость дальнейшего обучения, а не подвергаются давлению со стороны. Они имеют возможность работы с учебными материалами в таком режиме и объеме, который подходит непосредственно им. Эффект в значительной степени зависит от того, насколько регулярно занимается обучающийся. Последовательное выполнение контрольно-диагностических заданий и выпускной работы, а также поддержка во всех вопросах со стороны преподавателякоординатора обеспечивает планомерное усвоение знаний ${ }^{2}$.

Продолжительность карантина и сопутствующие последствия в связи с распространением COVID-193 являются беспрецедентными в новейшей истории Украины. Образовательная отрасль не претерпела драматических изменений из-за невозможности применять технологии и методики, доказывая свою эффективность в предыдущие периоды ${ }^{4}$. До введения дистанционного образования участники процесса обучения, прежде всего родители, оказались совершенно неподготовленными. Школа во все времена выступала базовым социальным институтом, агентом социализации детей. Роль школы в жизни ромских общин трудно переоценить. Аюди ромской национальности страдают не только от материальных нужд, а во многих случаях также и от осознания собственной нереализованности и социальной не востребованности в обществе. Дия детей-ромов школа выполняет кроме образовательной функции еще и функцию социальной защиты

\footnotetext{
2 В. Штилвелд, Дистаниійне навчання - від теорії до практики, актуальний мережевий семінар, http://www.osvita.org.ua/distance/articles/15/, (дата доступа: 17.12.2020).

3 О пандемии COVID-19 смотри шире: I. Krastew, Nadeszło jutro. Jak pandemia zmienia Europe, Warszawa 2020; A. Miller, Przez Chiny w ogniu koronawirusa, Katowice 2020; S. Žižek, Pandemia! COVID-19 trzessie światem, Warszawa 2020.

4 Дия сравнения, о дистанционном обучении в Польше в условиях COVID-19, смотри шире: Edukacja w czasach pandemii wirusa COVID-19. Z dystansem o tym, co robimy obecnie jako nauczyciele, ред. J. Pyżalski, Poznań 2020; Zdalne uczenie się $i$ nauczanie a specjalne potrzeby edukacyjne. $Z$ doświadczeń pandemii Covid-19, ред. Е. Domagała-Zyśk, Lublin 2020.
} 
(на базе школы проводятся медицинские осмотры детей, обеспечиваются горячие обеды).

По данным Всеукраинской переписи населения 2001 г. в Украине проживает 47,6 тыс. ромов (цыган) или 0,1\% всего населения страны. За прошедшее с переписи время количество миц цыганской национальности увеличилось. По оценке общественных организаций, больше всего их в Закарпатской области - более 20 тыс. человек. Большинство из них проживает в Ужгородском, Береговском, Виноградовском районах и в городах Ужгород и Мукачево. Хотя в последнее время наблюдается массовый выезд представителей цыганского населения за пределы области в поисках заработков. Поэтому, по нашему мнению, число ромов является меньшим, чем заявляют общественные активисты. В других регионах также заметно присутствие цыганского меньшинства: в Одесской области проживает 14 тыс. человек (по данным общественных активистов - до 20000 человек), в Харьковской - около 8000 человек, в Запорожской области проживают до 17000 человек, в Донецкой области - 6000 человек, в Черкасской области - 5-7 тысяч человек, в Херсонской - 2500 чемовек, и в Аьвовской области 0,8 тысяч человек цыганской национальности ${ }^{5}$. По мнению В. Крисаченко, цыгане в иерархии национальных меньшинств Украины занимают едва ми не последнее место. Это объясняется тем, что цыганские общины имеют негласный статус бездомных, бесперспективных, неспособных к интеграции сообществ, которые отчуждены из-за предубеждений, существующих в украинском населении, а позиция официальных властей остается практически нейтрально-отстраненнойб

В период с июня по сентябрь 2020 Закарпатским областным благотворительным фондом "Благо", при содействии Ужгородского национального университета, быц осуществлен опрос родителей детей-ромов о вмиянии карантинных

5 Р. Зіменко, Навчання ромів на Закарпатті. Чому освіта для ромів - ие ключ до інтеграиї в українсъке суспільство, http://www.chirikli.com.ua/ index. $\mathrm{php} / \mathrm{ua} / \mathrm{programi} /$ partnerstvo-dlya-vsikh/item/232-navchannia-romiv-na-zakarpatti-chomu-osvita-dlia-romiv-tse-kliuch-do-intehratsii-v-ukrainske-suspilstvo, (дата доступа: 06.09.2020).

6 В.С. Крисаченко, Цигани в Україні: сучасні проблеми, „Політологічний вісник” 2015, Вип. 77, с. 405-426. 
мероприятий на доступ к образовательным услугам указанной группы населения. Объем выборочной совокупности составил 1250 человек, а выборочным методом избраны непропорциональные формы стратифицированного отбора. Таким образом, в избирательной совокупности присутствовали следующие группы респондентов: родители детей-ромов Одесской области - 301 человек, Запорожской - 235 человек, Закарпатской - 184 человека, Харьковской - 159 человек, Донецкой - 149 человек, Черкасской - 108 человек, Херсонской 59 человек, Аьвовской - 55 человек. В каждой из групп была проведена простая случайная выборка на основе имеющихся телефонных номеров.

В исследовании приняли участие категории трудоспособного и не трудоспособного возраста. Самому молодому респонденту исполнилось 17 мет, а самому старшему 71 год. Средний возраст респондентов - 33,4 года. Наиболее представленными среди респондентов явцяются молодые мюди в возрасте 29 года - 8,5\% всех респондентов. Группа молодых родителей в возрасте 16-27 мет составляет в общей структуре выборки 18\%. Что касается распределения по полу, то респондентов мужского пола оказалось 25,8\%, а женского $74,2 \%$. Такая структура выборки обусловлена широкой представленностью женщин в родительских комитетах, и, очевидно, отражает фракт, что мужчины меньше внимания уделяют обучению своих детей и неосведомленные с образовательными проблемами.

Учитывая общую ситуацию в стране, ромы весьма негативно оценивают собственное материальное положение. Почти треть респондентов (31,5\%) утверждает, что они едва сводят концы с концами, иногда не хватает на питание. Еще почти половина (45\%) респондентов утверждают, что на питание хватает, но приобретение одежды или обуви вызывает трудности. $19,7 \%$ респондентов утверждают, что доходов им в целом хватает, однако приобретение ценных вещей вызывает затруднения. К самым богатым, то есть тем, кто может позволить себе практически все, за исключением особо крупных покупок (жилья, дорогого автомобиля и т.п.) причисляют $2,7 \%$ респондентов (рис.1). 
Пандемия COVID-19 серьезно повлияла на материальное благосостояние родителей детей цыган. При оценке динамики благосостояния в последние полгода, почти две трети респондентов $(60,8 \%)$ отметили, что их благосостояние значительно ухудшилось. Еще $30,6 \%$ респондентов заметили незначительное ухудшение своего благосостояния (рис. 2).

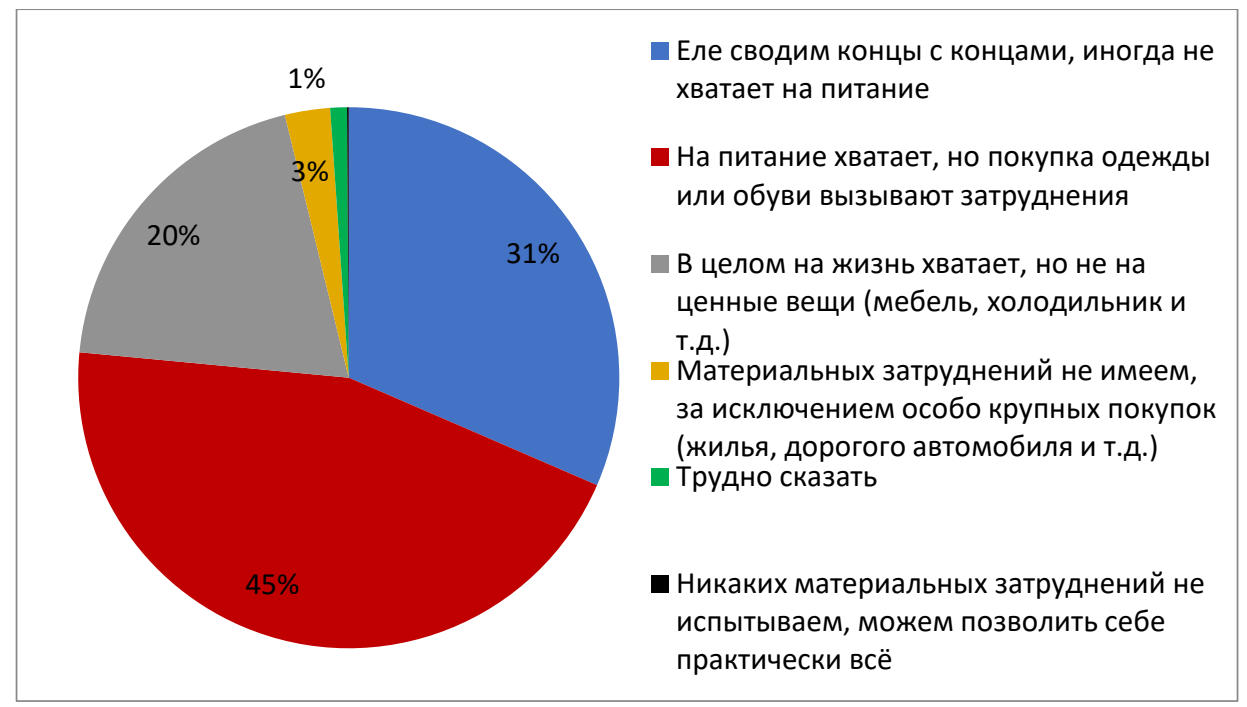

Pис. 1. Материальное положение семьи респондентов

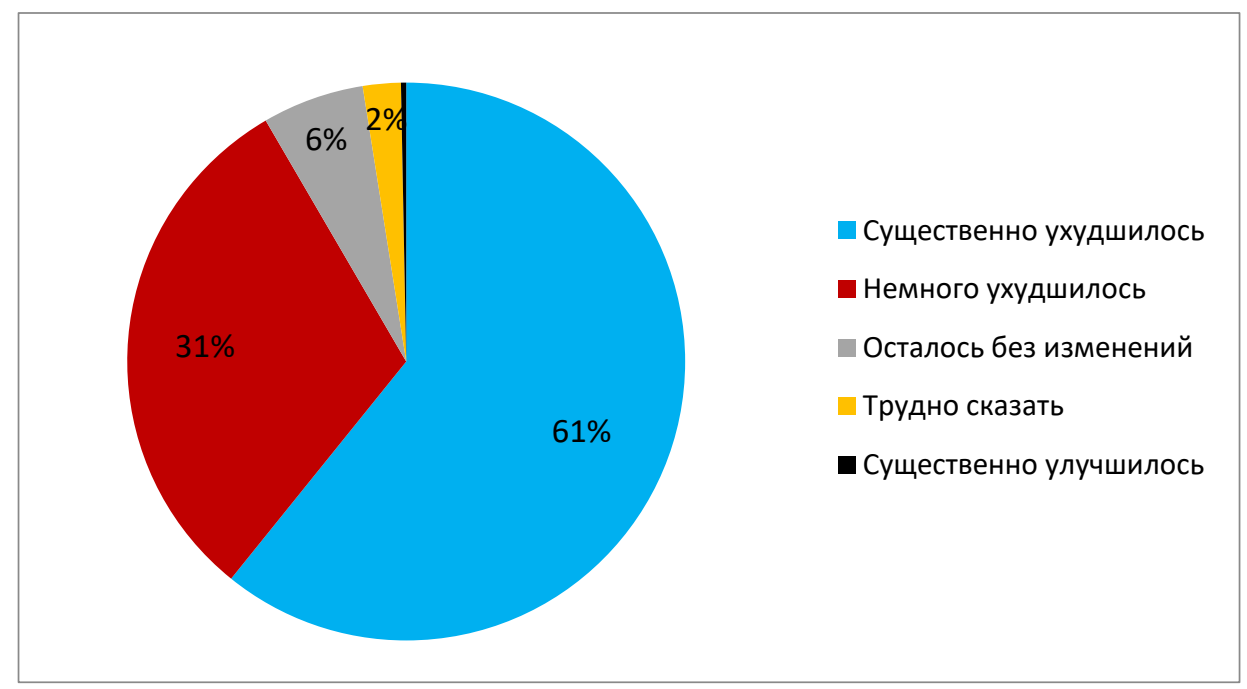

Рис. 2. Материальное положение респондентов в последние полгода 
В целом, по словам респондентов, пандемия COVID-19 обошла стороной их семьи. Аишь четверо респондентов, переболевших COVID-19, а 3,8\% утверждали, что этой болезнью переболели члены их семей. Знакомых, которые переболели этой болезнью имеет $27 \%$ респондентов. $48,2 \%$ человек заявили, что никого не знают, кто бы заболел COVID-19, а 15\% респондентов не верят в подиинность угрозы пандемии. Следует сказать, что цыганские семьи традиционно являются многодетными. В семьях респондентов среднее количество детей составляет 2,9, а медианное значение - 3 ребенка на семью (для сравнения, в целом по Украине среднее количество детей на семью составцяет 1,4). Количество детей школьного возраста среди общего числа респондентов составцяет $61,1 \%$ от всех указанных в опросе детей.

Абсолютное большинство респондентов утверждает, что их дети регулярно посещали школу к пандемии (96\%). Однако только 10\% респондентов утверждают, что их дети не имели пропусков занятий в школе. Почти половина респондентов (45\%) выбрали ответ "Да, пропускали раз в месяц или реже", а 30,1\% выбрали ответ "Да, несколько раз в месяц". На самом деле, это оценочное суждение свидетельствует об осведомленности родителей относительно пропускав детей в школе, однако, точное количество пропусков они не отслеживают через свое нежелание или по другим причинам.

Наиболее частой причиной пропусков родители указали заболевания ребенка (в 70,5\% случаев), а почти половина случаев пропусков (40,7\%) была обусловлена праздниками и различными мероприятиями в семье или ромской общине. Каждый седьмой из опрошенных считает, что ребенок может пропускать занятия в школе из-за необходимости ухода за хозяйством и другими членами семьи (в соответствии 17,5\% и 16,3\% респондентов). $2,5 \%$ респондентов утверждают, что их дети чувствуют враждебное отношение к себе и поэтому не посещают школу. Отдельные респонденты отмечали следующие причины: дети посещают школу только зимой; живут во временном поселении и поэтому их дети не ходят в школу; не имеют средств, чтобы отправить ребенка в школу (рис. 3). 


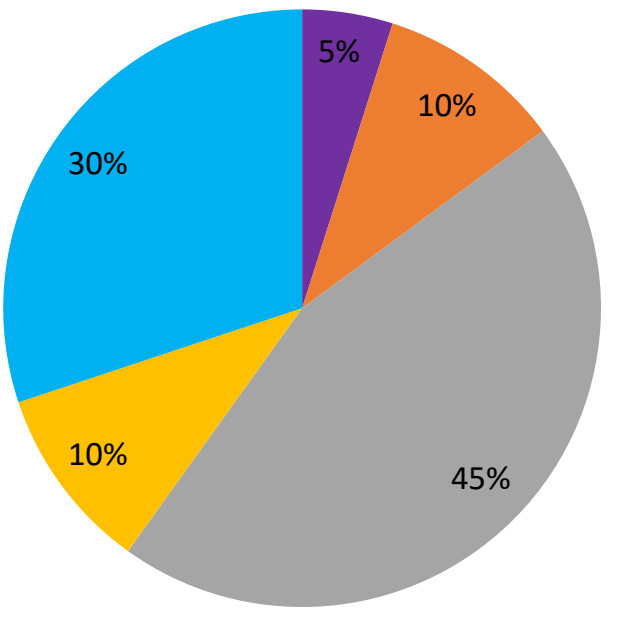

Трудно сказать

Да, пропускали раз в неделю или чаще

Да, пропускали раз в месяц или реже

- Нет, не пропускали

口 Да, пропускали несколько раз в месяц

Рис. 3. Посещение занятий в школе детей респондентов до пандемии

Среди причин, почему их дети посещают школу, то 67,5\% респондентов отметили получение знаний и навыков; 35,6\% общение с одноклассниками; 24\% - престижность статуса школьника, 19\% - дружескую атмосферу. Также причинами посещать школу родители указывали возможность обедать в школе $(17,4 \%)$ и возможность отдохнуть от семейных обязанностей $(8,9 \%)$ (рис. 4).

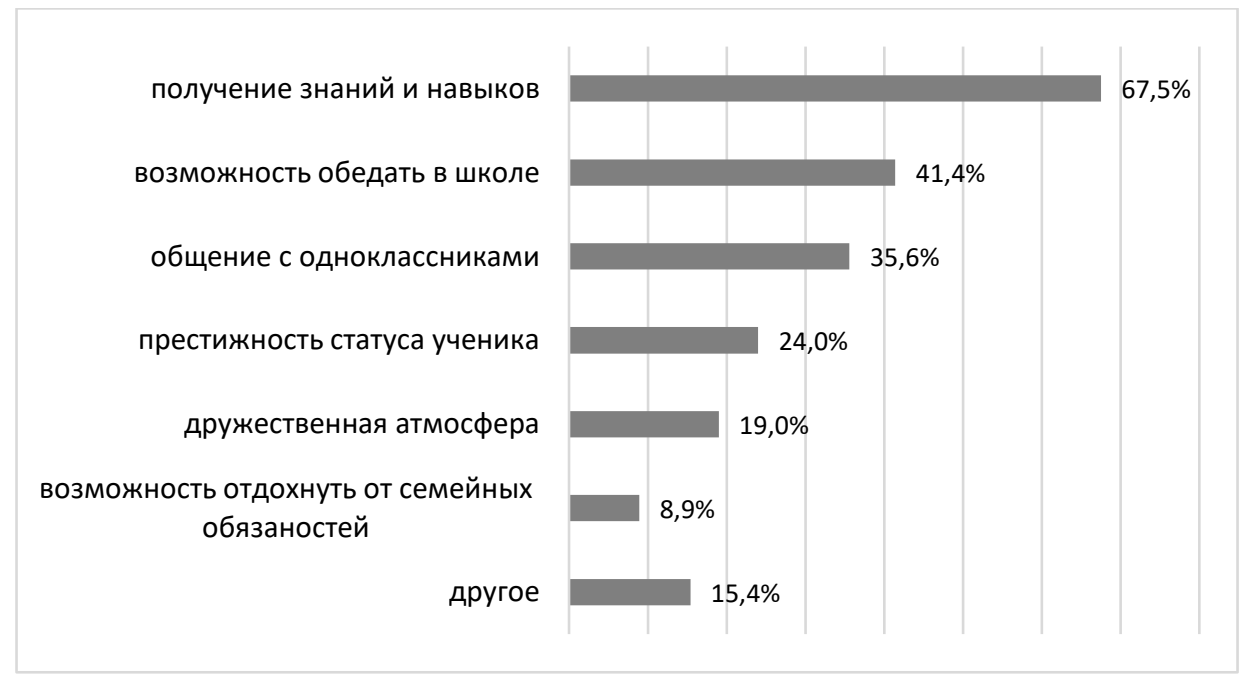

Рис. 4. Мотивация детей заниматься в школе 
В ходе нашего исследования мы ставили вопрос о пользе посещения занятий в школе. Дия 56,6\% респондентов такая польза заключается в возможности трудоустроиться на престижную работу после окончания школы. Дия 55,4\% респондентов польза заключается в развитии собственного ребенка в шкоцьном колмективе. Некоторые респонденты считают, что посещение школы будет полезным для того, чтобы ребенок начал ценить тяжелый труд родителей $(13,5 \%)$, а 5,4\% респондентов считают, что за время пока дети в школе они могут отдохнуть от ухода за ними. Зато, 6,8\% респондентов никакой пользы в посещении детьми школы не видят (рис. 5).

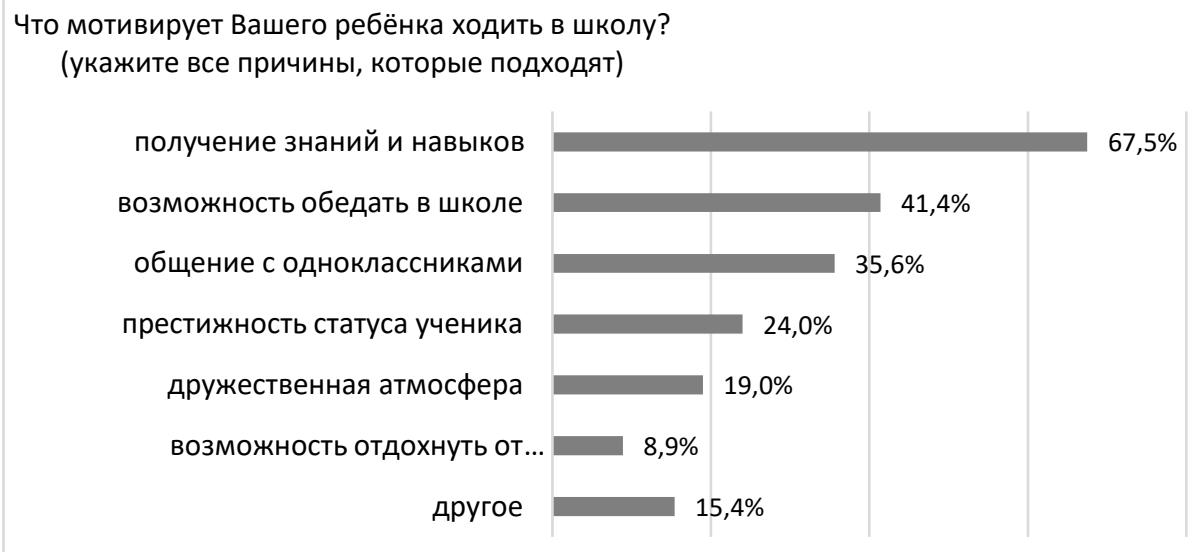

Pис. 5. Причины посещения занятий в школе

Важным элементом социальной атмосферы в школьном комлективе являются взаимоотношения в треугольнике "отцыдети-учителя". $67,6 \%$ респондентов отметили, что их дети хорошо себя чувствуют в школе и в них отсутствуют конфцикты. $17,9 \%$ родителей отметили, что их дети подвергаются травле со стороны других детей, 11,8\% указали, что их дети испытывают бумлинг со стороны учителей и $6,4 \%$ отметили факты бумиинга со стороны администрации шкомы. Некоторые респонденты высказывали мнение, что насилие против цыганских детей воспроизводится в школах "из поколения в поколение» (рис. 6).

За время пандемии обострилось много проблем жизнедеятельности цыган. 45,9\% респондентов отметили, что 
сталкивались с необходимостью поиска работы, 21,9\% почувствовали трудности в получении социальной помощи, $18,5 \%$ столкнулись с барьерами в получении образования дмя себя или своих детей. Отдемьные респонденты также испытывали трудности в оформлении паспорта или регистрации места житемьства (10,2\%), получении правовой помощи $(2,9 \%)$, осуществлении предпринимательской деятельности $(2,8 \%)$, преследования и притеснения со стороны помиции $(1,6 \%)$ и т.д. (рис. 7).

дети ощущают буллинг со стороны учителей

дети подвергаются травле со стороны других детей

дети ощущают буллинг со стороны администрации школы

дети хорошо себя чуствуют в школе и у них отсутствуют конфликты

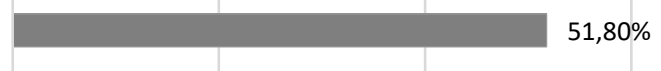

другое

$8,40 \%$

Рис. 6. Отношение к детям в школе

Расскажите, пожалуйста, стыкались ли Вы со такими проблемами

с начала пандемии? (укажите все проблемы, которые подходят)

$$
\text { труднк работы }
$$

барьеры в получении образования для себя или своих детей

трудности в оформлении паспорта или регистрации места жительства

получение правовой помощи

осуществление предпринимательской деятельности

преследования и ущемление прав со стороны полиции

другое

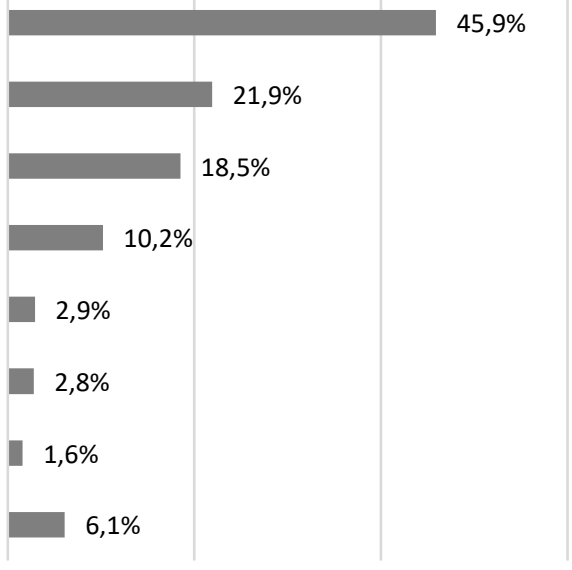

Рис. 7. Проблемы респондентов 
Проблемы с работой актуальны дия большинства респондентов. Так, только 11,7\% респондентов имеют постоянное место работы и работают ежедневно. Еще 26,6\% респондентов утверждают, что ходят на работу время от времени. Часть респондентов конкретизировала характер своей временной работы. Так, наиболее распространенными видами временной работы является сбор металолома, сортировка мусора, сбор урожая (орехов, картофеля), выпас скота, торговля. 3,4\% респондентов работают дистанционно. Каждый четвертый респондент $(22,6 \%)$ потерял работу во время пандемии и диительного карантина. 5,6\% респондентов находятся на учете центров занятости. Однако, 15,9\% респондентов никогда не работала. Среди других ответов, респонденты отмечали отсутствие работы через декретный отпуск и уход за детьми, выход на пенсию и т.п.

Дıя решения наиболее насущных проблем ромы не привыкли обращаться в государственные или неправительственные организации. $13,7 \%$ респондентов отметили, что для решения вышеупомянутых проблем они обращались в территориальные органы социальной защиты, 8,6\% - в органы Государственной службы занятости, 3,7\% обращались в городские, поселковые, сельские советы, 2,3\% - в больницы, $1,9 \%$ - к представителям неправительственных организаций. Единичные обращения респонденты демали в полицию, школы, ЗАГС, ЦНАП, государственную миграционную службу и т.п. Однако, довольно заметная часть респондентов выразила сомнения в эффективности обращения к разАичным скужбам и организациям из-за предвзятого отношения к мицам ромской национальности.

ВАияние материальной необеспеченности ощущается в доступе рома к цифровым технологиям. Наиболее распространенным цифровым устройством является смартфон им владеют 65,3\% респондентов. Пцаншетом обеспечены семьи $17,1 \%$ респондентов. Ноутбук имеют $14,9 \%$ респондентов, а персональный компьютер - 6,2\%. Зато, наиболее распространенным средством связи в семьях рома является кнопочный телефон. Еще сложнее ситуация с доступом ромов к 
сети Интернет. 17,3\% респондентов вообще пользуются сетью Интернет. Еще 27,4\% респондентов пользуются Интернетом только в публичных местах. 27,9\% заявили, что доступ к Интернету получают через беспроводное соединение роутером, а $27,1 \%$ имеют проводное подключение через модем.

Почти половина родителей заявили, что их дети не имели никаких контактов со школьными учителями (41,2\%). 31,1\% респондентов заявили, что учителя давали задания детям дистанционно, однако дети выполняли их выборочно. 22,7\% респондентов утверждали, что их дети добросовестно выполняли все задания. Почти в каждой третьей семье $(29,6 \%)$ домашние задачи не выполнялись вообще. $7,2 \%$ респондентов высказали мнение, что задачи учителей были несложными и поэтому с ними не было проблем у ребенка. 30,2\% респондентов утверждали, что задачи были тяжелыми, однако, ребенок пытался их выполнять самостоятельно. Еще в семьях 26,2\% респондентов задачи выполнялись совместно родителями и детьми. $22 \%$ респондентов заявили, что их дети просматривали Всеукраинскую школу онцайн по телевидению. $7,8 \%$ респондентов с ней незнакомы.

Почти две трети респондентов указали на то, что образовательное развитие их детей ухудшилось (31,4\% - выбрали ответ "значительно ухудшилось", 29,8\% - выбрали ответ "несколько ухудшилось"). 20,7\% респондентов отметили, что образовательное развитие их детей претерпело изменения за время пандемии. Большинство родителей утверждают, что падение уровня знаний произошло по всем предметам одновременно. Однако, 76\% респондентов отметили, что больше всего уровень знаний детей упал по математике, 58,2\% указали, что самым заметным является падение уровня знаний по украинскому языку и митературе (в начальных классах все предметы "книга для чтения" и "письмо»), 25,4\% отметили, что больше всего уровень знаний детей упал по фризике, а 22,7\% указали, что самым ощутимым является падение уровня знаний по истории.

Как выход из проблемы падения уровня знаний родители предлагают проведение дополнительных уроков следующего учебного года (66\%), работа с репетиторами $(28,9 \%)$, посещение 
"Уличной школы" (14,6\%), самостоятельная работа учащихся $(11,2 \%)$, фокусированное дистанционное обучение по предметам со снижающимся образовательным уровнем $(7,1 \%)$. Некоторые респонденты отмечали, что в условиях отсутствия средств, будут использовать наиболее доступные способы повысить образовательный уровень своих детей.

Не менее интересно и важно мнение педагогов, ведь дистанционное обучение дмя них оказалось вызовом. В исследовании приняли участие 925 педагогов. Возрастные характеристики респондентов охватывают все когорты трудоспособного и нетрудоспособного возраста. Самому молодому респонденту исполнилось 19 цет, а самому старшему - 71 цет. Средний возраст респондентов - 43,2 года. Наиболее представленными среди респондентов были педагоги в возрасте 48 мет $-4,5 \%$ всех респондентов. Группа момодых педагогов в возрасте 19-30 ^ет составляет в общей структуре выборки 18,5\%. Что касается распределения по полу, то респондентов мужского пола оказалось 8,9\%, а женского - 91,1\%. Такая структура выборки обусловлена широкой представленностью женщин в педагогических комлективах. $\mathrm{K}$ тому же мужчины чаще уклонялись от участия в опросе. Субъективными признаками мы можем назвать их незаинтересованность в цели исследования.

В ходе исследования выяснялась продолжительность педагогического стажа у респондентов. Средняя продолжительность такого стажа составима 20,0 мет. 1,3\% респондентов педагогический стаж до 1 года, а 5,7\% респондентов имеют стаж более $40 \quad \Lambda е т$ (максимальная продолжительность педагогического стажа среди респондентов составица 50 мет).

Распределение респондентов по должностям оказалось следующим: 42,4\% является учителями старших классов, 25,8\% - учителя начальных классов, $16,5 \%$ - работники дирекции образовательных учреждений, 7,4\% - педагоги-организаторы, психологи, социальные педагоги, 3,2\% - ассистенты учителя, стажеры, практиканты и другие специалисты.

Что касается предыдущего опыта дистанционного образования к пандемии COVID-19, то 36,7\% респондентов 
заявили, что имели подобный опыт, 60,4\% отрицали наличие опыта дистанционного образования, а 2,9\% затруднились с ответом (рис. 8).

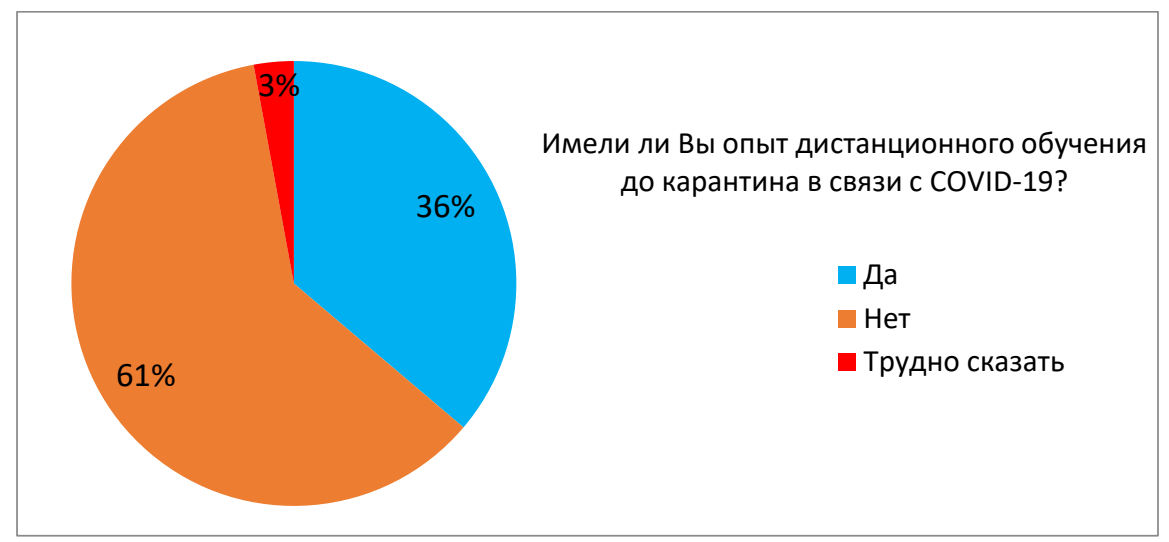

Pис. 8. Предыдущий опыт дистанционного обучения

Интересными оказались рассказы респондентов по их непосредственному опыту дистанционного образования. Наиболее интересными оказались следующие рассказы: “Ученики выполняли задания на сайте "На урок", просматривали видеоролики по изучению учебного материала, который я посылала в группу в "вайбер", общалась с учениками и родителями в телефонном режиме" (женщина, 45 мет, Харьковская область), "необходимые технические средства, соответствующие этому учению, гаджеты" (женщина, 43 года, Одесская область), "за осложнения погодных условий ученики не могли посещать школу в зимний период (гололед, метели). С учениками организовывали обучение по телефону. Объясняли сложный материал, ученики отвечали устно домашние задания. Это бымо очень сложно" (женщина, 56 мет, Херсонская область), "работал в Zoom и Meet во время карантинов" (мужчина, 40 мет, Черкасская область), "работа с электронными журналами на портале "Новые знания", использование интерактивных плакатов, сервисов Google» (женщина, 38 мет, Донецкая область), "результативность показали учащиеся обеспечены качественными телефонами и интернетом, находящимися под наблюдением родителей. Эффективным такой учебный процесс назвать трудно, потому 
что таких меньшинство, самостоятельно учатся дистанционно единицы в средних классах" (женщина, 61 год, Харьковская область), «проводила уроки на платформе Zoom, посымала задачи в вайбер, наладила обратную связь по электронному ящику, работа через виртуальный класс" (женщина, 35 лет, Запорожская область), "проводияи онлайн-фото фмэш-мобы к праздникам и памятным дням" (женщина, 52 года, Херсонская область), "на сайте школы измагались задачи по предмету. Однако обратной связи было недостаточно, поскольку не все школьники имели возможность работать с интернет-ресурсом из-за отсутствия гаджетов, а иногда и отсутствия энергоснабжения. Кроме того, родители учеников не могли помогать детям, потому что сами компьютерно неграмотные" (женщина, 60 мет, Закарпатская область), "во время АТО, на территориях, где проводились боевые действия, было дистанционное обучение. В основном оно было похоже на самообразование, но под контролем учителя. Темы дия обработки выкладывали на сайт школы со ссылками на дополнительные источники. Дублировали эту информацию родителям в телефоне. К тому времени большую популярность имел скайп. Поэтому вся информация на скайп или в смс сообщения. Иногда видеосвязь. Тесное сотрудничество с родителями" (женщина, 29 мет, Херсонская область), "очень сумбурная и тяжелая дополнительная работа со стороны учителя и совершенно не упорядочен процесс обратной связи со стороны учеников" (женщина, 42 года, Запорожская область) и другие.

До введения карантина и дистанционного образования оказались полностью готовыми всего $4,1 \%$ респондентов. Однако, 40,6\% респондентов заявили, что оказались готовыми к дистанционному образованию в некоторой степени. В определенной степени не готовы $\mathrm{k}$ дистанционному образованию оказались 24\%, а полностью не готовы - 10,1\% респондентов. Колебался с ответом каждый пятый респондент $(20,4 \%)$ (рис. 9). 


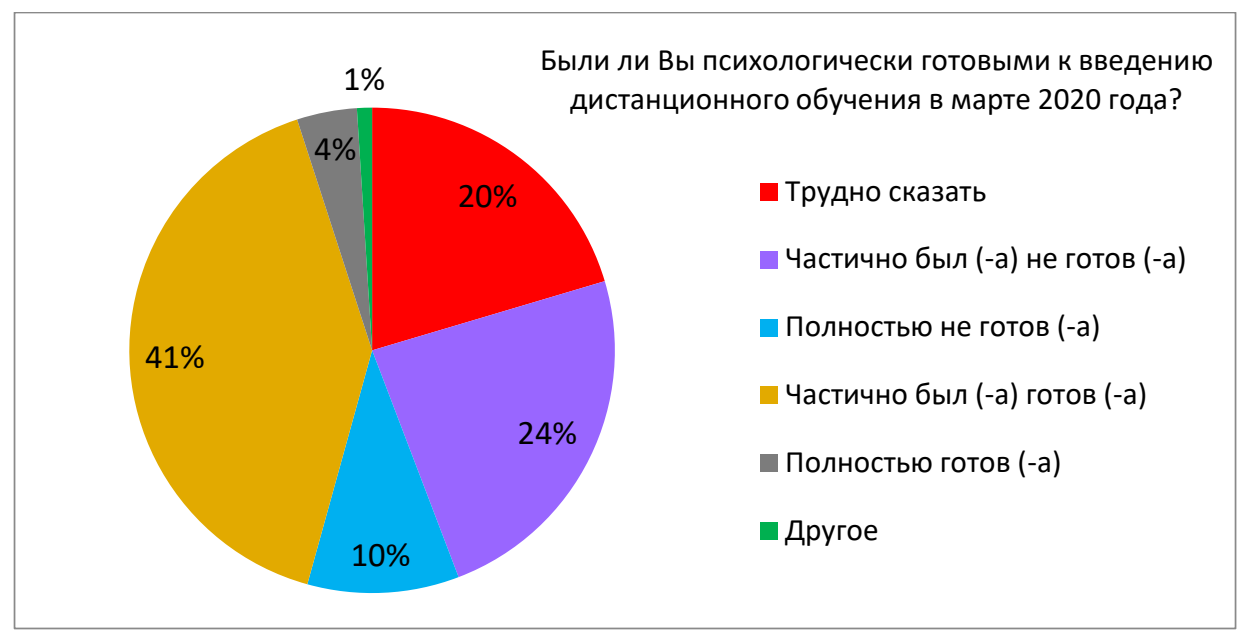

Рис. 9. Психологическая готовность педагогов

Во время пандемии COVID-19 дмя общения с учениками все учителя используют социальные мессенджеры (Viber, WhatsApp и т.п.) - 90,3\% респондентов телефонные звонки и CMC - 68,5\%, социальные сети (Facebook, Instagram и т.п.) $32,6 \%$, а еще $6,7 \%$ респондентов отдавало предпочтение мичным встречам. Отдельные образовательные ресурсы также пользовались популярностью: Classroom использовали 9,3\% респондентов, Zoom - 7,8\%. Еще 5,4\% использовали другие ресурсы ("Мой класс", MOODLE, "На урок", собственные блоги, сайты образовательных учреждений и т.д.).

В условиях карантина абсолютное большинство педагогов (92,3\%) рекомендовало к просмотру Всеукраинскую школу онлайн. По субъективной оценке учителей только треть цыганских детей (32,2\%) охвачена дистанционным образованием (оценка осуществлена на основе среднего значения ответов респондентов). Мнения респондентов относительно того, доступа цыганских детей к дистанционному образованию разделились следующим образом. Первый вариант "Доступ свободен" поддерживают $15,3 \%$ респондентов, вариант "Существуют опредеменные барьеры в доступе" - 28,1\%, вариант "Доступ узко ограниченный" - 25,2\%, вариант "Доступ отсутствует" поддерживают 7,4\% респондентов. Еще 22,4\% педагогов колебались с ответом на этот вопрос (рис. 10). 


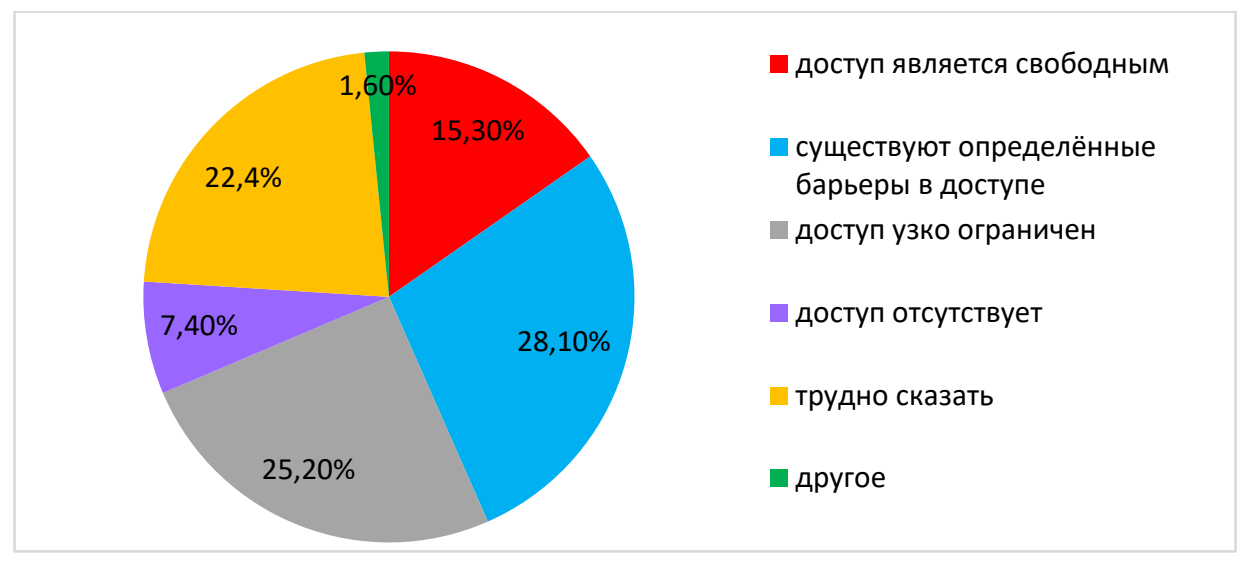

Pис. 10. Доступ цыганских ромских к дистанционному образованию

Респонденты также высказали свои мнения относительно препятствий в доступе к образованию у цыганских детей. 52,4\% респондентов считают основной проблемой отсутствие средств связи у детей и их родителей; $47,9 \%$ отметили препятствием непонимание содержания дистанционного образования родителями и учениками; $42,1 \%$ указали как основное препятствие нежелание цыганских родителей и учеников взаимодействовать с учителями; 34\% считают основным препятствием отсутствие контроля над выполнением задач; 11,9\% отметили необходимость поиска заработков в условиях прекращения производства, сокращение персонала на предприятиях; 2,5\% считают основным препятствием стигматизации, негативное отношение к цыганам со стороны других социальных групп.

В ходе данного исследования были собраны мнения относительно мичного отношения педагогов $\mathrm{k}$ внедрению карантина и его влияние на образовательный уровень детей. Следует сказать, что в $80,1 \%$ комментариев содержался термин "негатив" и его производные, поэтому в целом введение карантина создало ряд проблем различного характера. Среди мнений респондентов по этому вопросу можно выделить следующие: "В связи с распространением COVID-19 введение карантина было оптимальным решением для безопасности всех участников образовательного процесса. Но учитывая специфику 
работы с учашимися младшего школьного возраста, было немного сложно наладить качественное дистанционное обучение.

«Не все дети имели возможность пользоваться средствами дистанционного обучения каждый день и поэтому системность получения знаний не была цельной" (женщина, 23 года, Закарпатская область), "считаю, что карантин не должен быть долгосрочным, это влияет на образовательный уровень детей. Дети должны, во-первых, быть в социуме, а не перед компьютерами дома, во-вторых, не все родители могут уделять внимание обучению дистанционно, не у всех детей есть гаджеты" (мужчина, 42 года, Херсонская область), "для детей, имеющих мотивацию к обучению и контроль со стороны родителей, изменения несущественные" (мужчина, 45 мет, Харьковская область), "ради сохранения здоровья детей карантин необходим, но образовательный уровень учеников на дистанции снижается, так как живое общение с ребенком ничем не заменить" (женщина, 56 мет, Донецкая область), "негативное отношение к введению карантина, ничто не заменит "живого" общения, освоение детьми программы, на мой взгляд, не является 100\%" (женщина, 37 мет, Черкасская область), "отсутствие контакта между учеником и учителем негативно влияет на уровень образования (ребенок хочет иметь ответ на вопрос сейчас, а не позже)" (женщина, 52 года, Одесская область).

От 55,8\% респондентов непосредственно работающих с ромскими детьми также были получены ответы на два вопроса. На вопрос: "Как Вы считаете, увеличивается вероятность того, что в следующем году некоторые цыганские дети, в частности девочки-подростки, покинут школу в связи с COVID-19?» 17,1\% респондентов согласились с этим мнением, 32,7\% не согласились и $50,1 \%$ респондентов затруднились с ответом. На второй вопрос: "В условиях продмения карантина в 2020/2021 учебном году, будете ки Вы более подготовленными к работе с детьми цыганами?" были получены следующие ответы: полностью готовыми оказались $24,2 \%$ респондентов, в определенной 
степени готовыми 47,3\%, в опредеменной степени не готовы $2,7 \%$ и полностью не готовы оказались только 0,7\% педагогов.

Подводя итоги исследования, следует сказать, что выдвинутые гипотезы в целом подтверждены. Только треть педагогов оказалась частично готовыми $\mathrm{K}$ внедрению дистанционного образования, хотя этот опыт фрагментарен и не системен. Самообразование педагогов обычно помогало преодолевать вызовы дистанционного образования. Доминирующей мыслью учителей является то, что основным барьером в доступе детей-ромов к дистанционному образованию стало отсутствие средств связи и низкий приоритет образовательных потребностей вообще. Многие педагоги также отметили, что препятствием стало непонимание содержания дистанционного образования цыганскими родителями и учениками.

В заключение следует сказать, что родители детей-ромов оказались не готовы к внедрению дистанционного образования, связь с учителями почти не поддерживалась. К тому же, низкий уровень материального благосостояния существенно повлиял на образовательный уровень их детей (отсутствие одежды и обуви часто становилось препятствием в посещении школы еще до карантина).

Результаты опроса свидетельствуют, что, хотя внедрение дистанционного образования в образовательных учреждениях и застало педагогов неожиданно, однако они быстро смогми отреагировать на вызовы времени (причем, независимо от возраста и статуса в образовательной иерархии). С момента введения карантина учителя овладели социальными сетями, мессенджерами и активно используют образовательные платформы. Стоит отметить, что национальная принадлежность учеников изредка играет решающую роль в педагогическом процессе. Учителя с пониманием относятся к менталитету представителей цыганской национальности и, в условиях непосещения школы, находят другие способы контакта с учениками.

Следует сказать, что по результатам опроса родителей и учителей, непосредственно работающих с детьми-ромами в 
более позитивном ключе оценивают будущую работу с восполнением образовательной программы, чем родители. Основным барьером в доступе детей-ромов к дистанционному образованию стало отсутствие средств связи и низкий приоритет образовательных потребностей вообще. Низкий уровень владения современными цифровыми средствами связи исключает в процессе дистанционной учебы. Введенная правительством Всеукраинская школа онлайн оказалась недоступной и неинтересной ромской общине. Проблемой также является отсутствие единого видения у родителей относительно путей повышения образовательного уровня детей. Поэтому решение вопроса с восполнением школьной программы необходимо делать в триаде "государство-школа-родители".

\section{Бибмиография / References}

Afanas'êv D.M., Džugan R.İ., Nadannâ osvitnìh poslug ditâm - romam v umovah pandemiï COVID-19: rezul'tati sociologičnogo doslìdžennâ, [v:] Nadannâ social'nih poslug $v$ umovah decentralizaciï: problemi ta perspektivi. Materìali dopovidej ta povidomlen' Mižnarodnoï naukovo-praktičnoï konferencï (m. Užgorod, 25 veresnâ 2020 r.), red. O. Bartoš, S. Litvinova, V. Panok, F. Šandor, Užgorod 2020, [Афанасьєв Д.М., Джуган Р.І., Надання освітніх послуг дітям ромам в умовах пандемії COVID-19: результати соиіологічного дослідження, [в:] Надання соиіальних послуг в умовах деиентралізаиії: проблеми та перспективи. Матеріали доповідей та повідомлень Міжнародної науково-практичної конферениї (м. Ужггород, 25 вересня 2020 р.), ред. О. Бартош, С. Аитвинова, В. Панок, Ф. Шандор, Ужгород 2020].

Edukacja w czasach pandemii wirusa COVID-19. Z dystansem o tym, co robimy obecnie jako nauczyciele, red. J. Pyżalski, Poznań 2020.

Krastew I., Nadeszło jutro. Jak pandemia zmienia Europe, Warszawa 2020.

Krisačenkov. S., Cigani v Ukraïni: sučasnì problemi, „Politologičnij vìsnik" 2015, Vip. 77, [Крисаченко В.С., Цигани в Україні: сучасні проблеми, „Політологічний вісник” 2015, Вип. 77].

Miller A., Przez Chiny w ogniu koronawirusa, Katowice 2020.

Štilveld V., Distancijne navčannâ - vìd teorï do praktiki, aktual'nij mereževij seminar, http://www.osvita.org.ua/distance/articles/15/, (data dostupa: 17.12.2020), [Штилвелд В., Дистаниійне 
навчання - від теорії до практики, актуальний мережевий семінар, http://www.osvita.org.ua/distance/articles/15/, (дата доступа: 17.12.2020)].

Zdalne uczenie sie i nauczanie a specjalne potrzeby edukacyjne. $Z$ doświadczeń pandemii Covid-19, ред. Е. Domagała-Zyśk, Lublin 2020.

Zìmenko R., Navčannâ romìv na Zakarpattì. Čomu osvita dlâ romìv - ce klūč dointegraciï $v$ ukraïns'ke, http://www.chirikli.com.ua/ index.php/ua/programi/partnerstvo-dlya-vsikh/item/232navchannia-romiv-na-zakarpatti-chomu-osvita-dlia-romiv-tsekliuch-do-intehratsii-v-ukrainske-suspilstvo, (data dostupa: 06.09.2020), [Зіменко Р., Навчання ромів на Закарпатті. Чому освіта для ромів - ие ключ до інтеграції в украӥнське суспільство http://www.chirikli.com.ua/index.php/ua/ programi/partnerstvo-dlya-vsikh/item/232-navchannia-romivna-zakarpatti-chomu-osvita-dlia-romiv-tse-kliuch-do-intehratsiiv-ukrainske-suspilstvo, (дата доступа: 06.09.2020)].

Žižek S., Pandemia! COVID-19 trzęsie światem, Warszawa 2020. 

Artykuly / Articles

Николай Куксачёв

ORCID: 0000-0003-3128-0941

kuksachou@philosophy.by

Национальная академия наук Беларуси

Институт философии

Бемарусь

\title{
Нравственная эмита: формирование, место и ромь в обшестве
}

\author{
Moral elite: formation, place and role in society \\ Duchowa elita: formowanie, miejsce i rola w społeczeństwie
}

DOI: 10.34739/doc.2020.17.07

\begin{abstract}
Аннотация: В переломные исторические моменты остро встает вопрос о силах, способных сплотить общество на принципах нравственности и морали. Такой объединяющей социальной группой автору видится нравственная элита. В работе сделана попытка выделить наиболее важные черты, характеризующие данную социальную группу, проанализировать социальные и психологические трудности, с которыми приходится сталкиваться представителям данной группы при реализации своих устремлений. Выделены важнейшие принципы, которыми обуславливается формирование нравственной культуры данной группы общества.
\end{abstract}

Ключевые слова: нравственная элита, страдание, теории элит, формирование нравственной культуры

Abstract: At critical historical moments, the question of the forces that can unite society on the principles of morality is acute. The author sees the moral elite as such a unifying social group. The paper attempts to identify the most important features that characterize this social group, to analyse the social and psychological difficulties that representatives of this group have to face when realizing their aspirations. The most important principles that determine the formation of the moral culture of this group of society are highlighted.

Keywords: moral elite, suffering, theories of elites, formation of moral culture 